\title{
Down-regulation of TCF21 is associated with poor survival in clear cell renal cell carcinoma
}

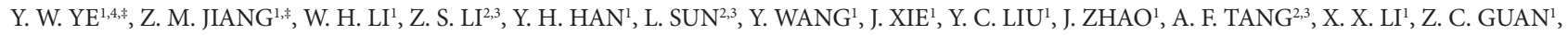 \\ Y. T. GUI ${ }^{1}$, Z. M. CAI $2,3, *$
}

${ }^{1}$ Guangdong and Shenzhen Key Laboratory of Male Reproductive Medicine and Genetics, Institute of Urology, Peking University Shenzhen Hospital, Shenzhen PKU-HKUST Medical Center, Shenzhen, China; ${ }^{2}$ Shenzhen Key Laboratory of Genitourinary Tumor, Shenzhen Second People's Hospital, First Affiliated Hospital of Shenzhen University, Shenzhen, China; ${ }^{3}$ The Institute of Urogenital Diseases, Shenzhen University, Shenzhen, China; ${ }^{4}$ Departement of Thoracic surgery, Peking University Shenzhen Hospital

${ }^{*}$ Correspondence: caizhiming2000@yahoo.com.cn

${ }^{*}$ Contributed equally to this work.

Received March 1, 2012 / Accepted April 11, 2012

\begin{abstract}
Transcription factor 21 (TCF21) has been identified as a candidate tumor suppressor at 6q23-q24 that is epigenetically inactivated in many types of human cancers. We recently found that TCF21 methylation level was significantly increased in clear cell renal cell carcinoma (ccRCC). The purpose of this study was to investigate the prognostic impact of TCF21 expression in ccRCC and analyze the relationship between TCF21 expression and methylation level. We used real-time PCR and immunohistochemical staining to detect the expression of TCF21, and used methylation specific-PCR (MS-PCR) to determine the methylation status of TCF21 in ccRCC samples and cell line 786-O. The results showed that TCF21 expression level in ccRCC samples was significantly lower than in normal adjacent tissue samples (NAT samples). The Kaplan-Meier survival analysis demonstrated that TCF21 was a significant prognosticator of cancer-specific survival $(p=0.001)$. Furthermore, the DNA demethylating agent 5'-azacytidine restored part of TCF21 expression by suppressing TCF21 methylation in 786-O. The methylation level of TCF21 in ccRCC samples was much higher than in NAT samples. These results suggest that the expression of TCF21 was an independent prognostic factor for poor survival in patients with ccRCC. Aberrant methylation was an important reason for the down-regulation the expression of TCF21, and may be associated with tumorigenesis in ccRCC.
\end{abstract}

Key words: TCF21, gene expression, methylation, clear cell renal cell carcinoma

Renal cell cancer is the third most common urological carcinoma with approximately 280,000 cases per year worldwide [1]. By far the majority histologic subtype of renal cancer is ccRCC [2]. There are currently no established tumor markers for ccRCC in clinical practice; tumor size, stage and location offer the only viable tools to predict prognosis [3]. A number of new molecular markers have been investigated, but none has gained approved clinical application [4]. Our recently research found that lots of genes are abnormally expressed in ccRCC [5]. There may be some genes that are involved in the development and progression of ccRCC.

Epigenetic mechanisms are essential for proper development and maintenance of normal gene expression. Disruption of epigenetic processes can lead to abnormal gene function and promote pathological conditions. DNA aberrant methylation is a crucial epigenetic modification of the genome that is involved in regulating many cellular processes, which include embryonic development, transcription, etc. Aberrant methylation is a major mechanism for silencing tumor suppressor genes in many kinds of cancers [6]. The analysis of DNA methylation biomarkers is an emerging field that provides promising potential for improving the clinical process of renal cell carcinoma diagnosis [7-11].

Based on our recent research in ccRCC, one gene named TCF21 drew our attention [5]. TCF21 is a transcription factor of the basic helix-loop-helix family, which product is mesoderm specific, and expresses in embryonic epicardium, mesenchyme-derived tissues of lung, gut, gonad, and kidney $[12,13]$. TCF21 as a candidate tumor suppressor at 6q23-q24 that is epigenetically inactivated in many kinds of cancers, including lung and head and neck cancer, and further research finding that aberrant methylation in lung cancer [14-19]. Aberrant methylation and decreased expression of TCF21 is tumor specific and very frequent in all NSCLCs, even 
early-stage disease, thus making TCF21 a potential candidate methylation biomarker for early-stage NSCLC screening [20]. Recent research found that methylation level was significantly high in renal cell tumor [3], but the relationship between TCF21 expression and methylation is not yet full understood, and the prognostic impact in ccRCC is still unclear.

We have showed that TCF21 is lower expressed in ccRCC samples than NAT samples in the 10 ccRCC patients [5]. In this study, we used immunohistochemistry to study the TCF21 in 186 ccRCC samples and NAT samples. The relationship between expression of TCF21 and survival time during the 6-year follow-up period was evaluated. In addition, we confirmed the methylation of TCF 21 gene in ccRCC cell line 786-O. The relationship between TCF21 methylation and expression level was also detected.

\section{Materials and methods}

Sample collection. A total of 186 ccRCC samples were obtained from the Biobank of Complex Diseases in Shenzhen between 2001 and 2007 in China. The NAT samples were defined as kidney tissues located $2.0 \mathrm{~cm}$ outside of visible ccRCC lesions. All the 186 patients' survival information was received by telephone. The median follow-up period was 69 months (range: 4 116months). Patients' clinical characteristics (gender, age, size, nodal status, metastasis and Fuhrman Nuclear Grade) were obtained from the medical records. No any treatment (chemotherapy or radiation) was before the operation. All resection samples were confirmed to be ccRCC by clinical pathology. The collection and use of the patient samples were reviewed and approved by Institutional Ethics Committees, and written informed consent from all patients was appropriately obtained. There were 36 cases of death within the observation time. Frozen tissues from 33 paired ccRCC and NAT samples were randomly selected from all 186 samples for extraction of DNA and RNA.

Cell line and culture. ccRCC cell line 786-O was obtained from the American Type Culture Collection (ATCC, Manassas, VA, USA) with $10 \%$ fetal bovine serum in a humidified incubator with $5 \% \mathrm{CO}_{2}$ and $95 \%$ air at $37^{\circ} \mathrm{C}$. These cells were passaged at a ratio of 1:3 with trypsin once they reached confluence (approximately $10^{7}$ cells) into $50 \mathrm{~cm}^{2}$ cell culture dishes.

Reverse transcription PCR (RT-PCR). Total RNA was extracted from ccRCC samples, NAT samples and cell line 786-O using TRIZOL (Invitrogen, USA) according to the manufacture's protocol and evaluated using Agilent 2100 Bioanalyzer (Agilent Technologies, USA).

RT was carried out by using Omniscript Reverse Transcriptase kit (Qiagen, Hilden, Germany). The total reaction volume was $20 \mu \mathrm{l}$ including $1 \mu \mathrm{g}$ RNA. The reaction mixture was incubated at $42^{\circ} \mathrm{C}$ for $60 \mathrm{~min}$, heated at $95^{\circ} \mathrm{C}$ for $10 \mathrm{~min}$ and then cooled on ice. The reaction was diluted 1:1 with water and aliquoted for further analysis.

Real-time PCR. Real-time PCR was carried out with SYBR Green dye in 7000 Sequence Detection System (Ap- plied Biosystems). Oligonucleotide primers were designed for human TCF21 and U6 gene, using the Beacon Designer 7 , based on their mRNA sequences. $1 \mu$ diluted cDNA aliquot was used as template for PCR in a total volume of 20 $\mu$ including TaqMan Universal PCR Master Mix and the corresponding probes and primers. The mixture was preincubated at $94^{\circ} \mathrm{C}$ for $10 \mathrm{~min}$ followed by 50 cycles of two step incubations at $94^{\circ} \mathrm{C}$ for $30 \mathrm{sec}$ and $58^{\circ} \mathrm{C}$ for $1 \mathrm{~min}$. All samples were measured in triplicates. The $\mathrm{Ct}$ value of TCF21 mRNA was normalized to the reference gene Ct (U6) and the relative quantification was performed according to Pfaff mathematical model.

Immunohistochemistry (IHC) analysis. Paraffin sections $(3 \mu \mathrm{m})$ from samples of $186 \mathrm{ccRCC}$ samples and 33 NAT samples were deparaffinized in $100 \%$ xylene and re-hydrated in descending ethanol series $(100 \%, 90 \%, 80 \%, 70 \%$ ethanol) and water according to standard protocols. Heat-induced antigen retrieval was performed in $10 \mathrm{mM}$ citrate buffer for $2 \mathrm{~min}$ at $100^{\circ} \mathrm{C}$. Endogenous peroxidase activity and non-specific antigen were blocked with peroxidase blocking reagent containing $3 \%$ hydrogen peroxide and serum, followed by incubation with goat anti-human TCF21 antibody for $1 \mathrm{~h}$ at $37^{\circ} \mathrm{C}$. After washing, the sections were incubated with biotin-labelled rabbit anti-goat antibody for $10 \mathrm{~min}$ at room temperature, and subsequently were incubated with streptavidin-conjugated horseradish peroxidase (HRP) (Maixin Inc, China). The peroxidase reaction was developed using 3, 3-diaminobenzidine chromogen solution in DAB buffer substrate. Sections were visualized with $\mathrm{DAB}$ and counterstained with hematoxylin, mounted in neutral gum, and analyzed using a bright field microscope.

Evaluation of staining. All of the IHC staining results were reviewed independently by two pathologists. Positive expression of TCF21 was defined as the brown staining in the cytoplasm. The staining results for TCF21 were scored semiquantitatively. Intensity was estimated in comparison to the control and scored as follows: 0 , negative staining; 1 , weak staining; 2 , moderate staining; and 3 , strong staining. Scores representing the percentage of tumor cells stained positive were as follows: $0,<1 \%$ positive tumor cells; $1,1-10 \% ; 2$, $10-50 \% ; 3,50-75 \%$; and $4,>75 \%$. A final score was calculated by adding the scores for intensity and percentage. For statistical analysis, 0-3 was counted as low expression of TCF21, while 4-7 was counted as high expression of TCF21.

DNA Extraction, Bisulfite Modification. Genomic DNA was extracted from cell line 786-O and tissues by Proteinase $\mathrm{K}$ digestion and salting-out method. DNA was loaded in agarose gel electrophoresis, and stained with ethidium bromide to check purity. Treatment of DNA with sodium bisulfite would result in the unmethylated cytosines being converted into uracils, while the methylated cytosines remained unchanged. Bisulfite conversion was carried out using the reagents provided in an EZ DNA Methylation Gold kit (Zymo Research, Orange, CA). $1 \mu \mathrm{g}$ of DNA was treated with sodium bisulfite according to the manufacturer's directions. The bisulfite-con- 
verted DNA was eluted in a total volume of $20 \mu \mathrm{l}$ and stored at $-20^{\circ} \mathrm{C}$.

Treatment with 5'-azacytidine. $786-\mathrm{O}$ cells were plated in 6-well plates at a density of $2 \times 10^{5}$ cells per well and allowed to attach for 24 hours. 5 -azacytidine (Sigma-Aldrich, St. Louis, MO, USA) was added directly to the culture media at a final concentration of $10 \mu \mathrm{M}$. Cells were treated for a 5-day period. Untreated controls were also prepared in parallel. At the 3-day, 4-day and 5-day of the treatment, cells were harvested, and DNA and RNA analysis were carried out. Three independent experiments were performed.

Methylation analysis. The methylation status of the exon $1 \mathrm{CpG}$ islands of the TCF 21 gene in 33 ccRCC samples, NAT samples and 786-O (before and after treatment with 5 '-azacytidine) were analyzed by methylation specific-PCR (MS-PCR) on sodium bisulfite modified DNA. The primers for the methylated sequences were FM-TCF21 (5'- TTT GGT TAA CGA TAA ATA CGA GAA CG -3') and RMTCF21 (5' - CCT AAA AAC TCT AAA CCC GCG AT -3'). The primers for unmethylated sequences were FU-TCF21 (5'- TTT GGT TAA TGA TAA ATA TGA GAA TGG -3') and RU-TCF21 (5'- TCC CTA AAA ACT CTA AAC CCA CAAT $\left.-3^{\prime}\right)$. The reactions were carried out in a total volume of $20 \mu \mathrm{l}$, containing $100 \mathrm{ng}$ genomic DNA, 10X PCR buffer, $0.2 \mathrm{mM}$ of each dNTP , $0.4 \mu \mathrm{M}$ of sense and antisense primers, 0.1 unit of FastStart TaqDNA Polymerase (Roche Diagnostics, Mannheim, Germany). Reaction mixtures were hot-started at $95^{\circ} \mathrm{C}$ for $5 \mathrm{~min}$. Amplification was performed in a Mastercycler gradient (Eppendorf, Humburg, Germany) for 54 cycles $\left(30 \mathrm{sec}\right.$ at $95^{\circ} \mathrm{C}, 30 \mathrm{sec}$ at $50^{\circ} \mathrm{C}$ and $30 \mathrm{sec}$ at $72^{\circ} \mathrm{C}$ ), followed by a final extension of $5 \mathrm{~min}$ at $72^{\circ} \mathrm{C}$. Twenty microliters of PCR product were electrophoresed in $2 \%$ agarose gel, stained with ethidium bromide, and photographed under UV light.

Statistical analysis. All statistical analyses were performed using SPSS 17.0 software. The $\chi^{2}$ test was used to analyze the relationship between the levels of TCF21 expression and clinicopathologic characteristics (gender, age, pT classification, pN classification, pM classification and Fuhrman Nuclear Grade ). The overall survival time of ccRCC patients was defined as the time from the surgery to death due to cancer. The Kaplan-Meier method was used to determine the cumulative probability of survival. The significances of various variables in survival were analyzed using multivariate Cox proportional hazards model. Fisher's exact text was used to determine the relationship between methylation levels and mRNA expression levels in ccRCC compared to NAT.A value of $p<0.05$ was considered statistically significant.

\section{Results}

TCF21 mRNA is frequently down-regulated in ccRCC. Real-time RT-PCR was performed to measure the expression of TCF21 mRNA transcripts in 33 ccRCC samples and NAT samples. Compared with NAT samples, most of ccRCC sam-

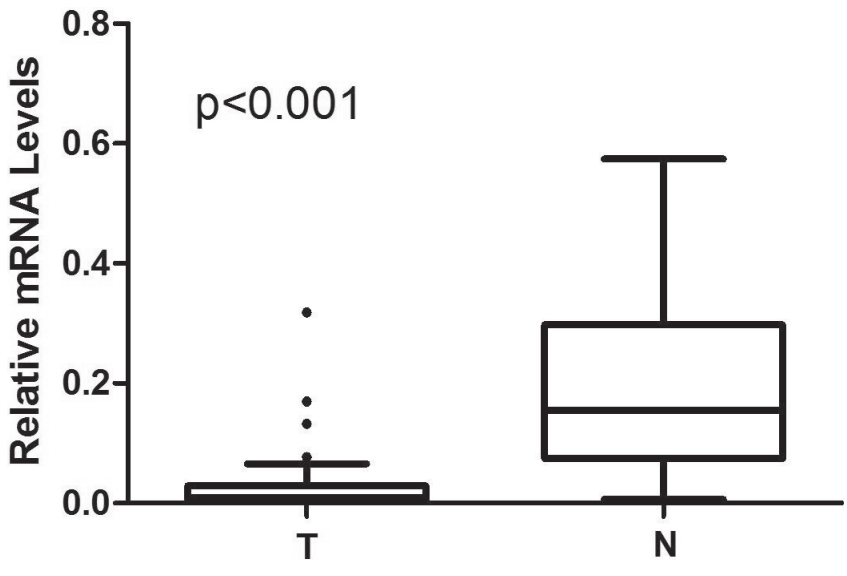

Figure 1. Down-regulation of TCF21 mRNA in ccRCC. Relative expression of TCF21 mRNA in ccRCC samples and NAT samples. TCF21 mRNA was lower expression in ccRCC samples compared with NAT samples $(p<0.001$, $\mathrm{n}=33$ ). Reactions were performed in triplicate and normalized to $U 6$ cycle threshold values. T, ccRCC samples; N, NAT samples.

ples (31/33) showed lower mRNA expression levels of TCF21 (Figure1, $p<0.001$ ).

Analysis of expression of TCF21 protein by immunohistochemistry. The expression of TCF 21 by immunoreactivity was mainly localised in the epithelial cells of kidney tissues and ccRCC cells (Figure2.A-C). The percentage of high expression (4-7 staining score) of TCF21 in ccRCC samples is $43.5 \%(81 / 186)$, which is significantly less than those in NAT samples $(87.9 \%, 29 / 33)$ (Table1, $p<0.001$ ).

Methylation status of TCF21 in ccRCC tissues. The methylation status of TCF21 was evaluated in 33 ccRCC samples and NAT samples by MS-PCR (Figure3). The methylation status of TCF 21 was detected in the ccRCC samples of 23/33(69.7\%). Meanwhile 14 of 33 cases (42.4\%) were observed in NAT samples, whose level obviously lower than ccRCC samples (Table2, $p=0.026$ ).

Table1. Protein expression of TCF21 between ccRCC samples (T) and NAT samples $(\mathrm{N})$.

\begin{tabular}{|c|c|c|c|c|}
\hline \multirow{2}{*}{ Group } & \multirow{2}{*}{ Case } & \multicolumn{2}{|c|}{ Protein expression } & \multirow[b]{2}{*}{$p$} \\
\hline & & Low & High & \\
\hline $\mathrm{T}$ & 186 & 105 & 81 & $<0.001^{*}$ \\
\hline $\mathrm{N}$ & 33 & 4 & 29 & \\
\hline
\end{tabular}

Table2. Methylation status of TCF21 between ccRCC samples (T) and NAT samples (N).

\begin{tabular}{ccccc}
\hline Group & Case & Methylated Unmethylated & $p$ \\
\hline $\mathrm{T}$ & 33 & 23 & 10 & $0.026^{*}$ \\
$\mathrm{~N}$ & 33 & 14 & 19 & \\
\hline
\end{tabular}



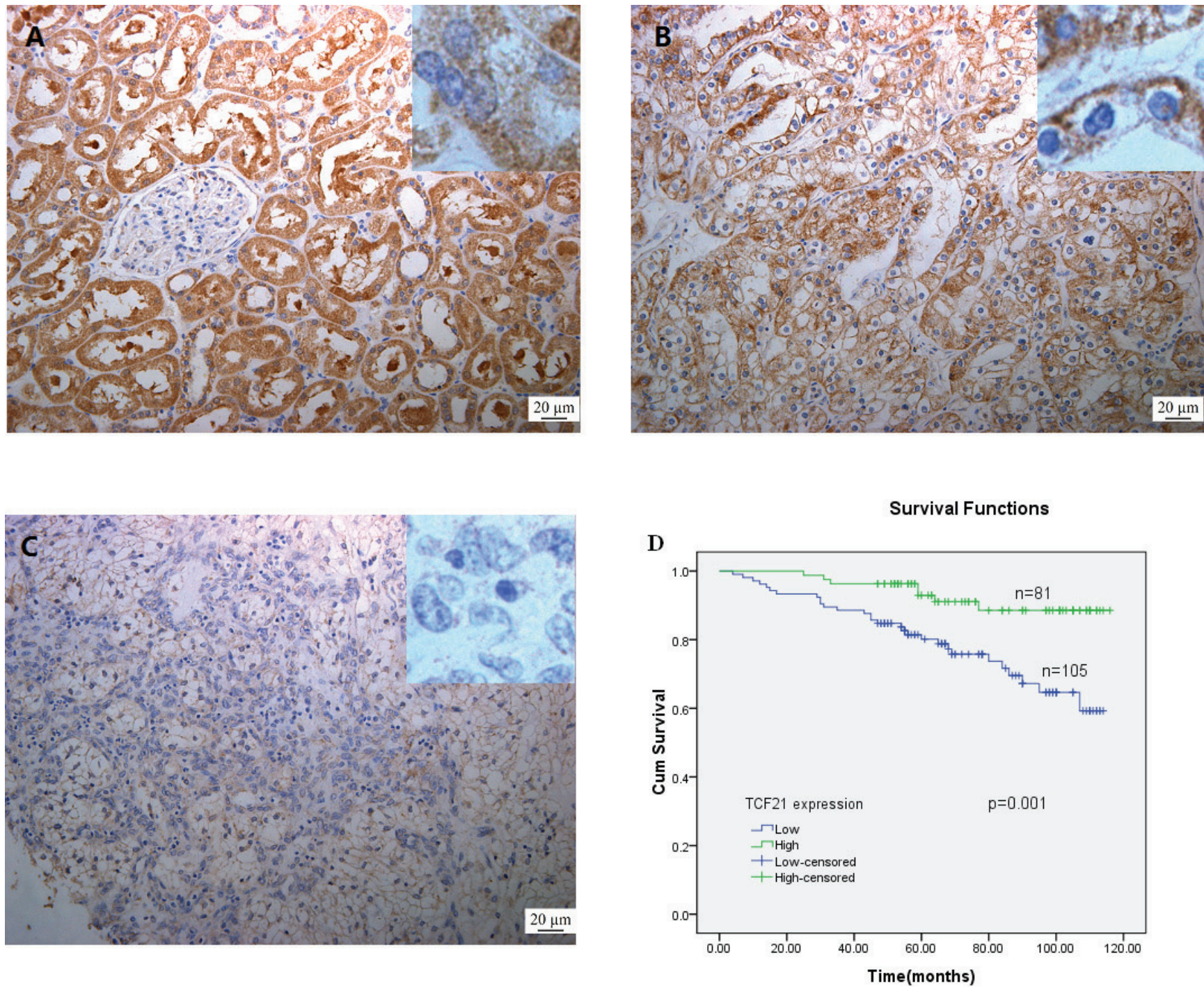

Figure 2. Immunohistochemical detection of TCF21 protein in ccRCC. A) High expression in epithelial cells of renal collecting ducts in NAT samples. B) High expression in Fuhrman Nuclear Grade I. C) Low expression in Fuhrman Nuclear Grade III. D) Kaplan-Meier survival analysis of overall survival duration in $186 \mathrm{ccRCC}$ patients according to TCF21 protein expression. The log-rank test was used to calculate $p$ values. High expression of TCF21 was associated with significantly improved overall survival $(p=0.001)$ in ccRCC.

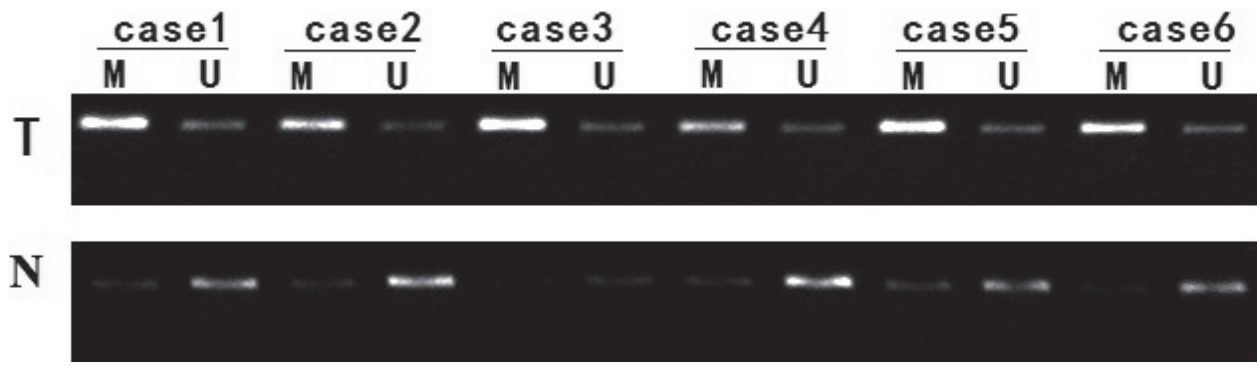

Figure 3. Methylation analysis of TCF21 in ccRCC. Methylation level in ccRCC samples much higher than that in NAT samples. T, ccRCC samples; N, NAT samples; M, methylated lane; U, Unmethylated lane. 
Methylation status in cell line 786-O. To evaluate the effect of aberrant methylation and chromatin configuration on the expression of TCF21, The methylation status of the TCF21 was analyzed by MS-PCR in the ccRCC cell line 786-O, which was also treated with a DNA methyltransferase inhibitor, 5 '-azacytidine. Treatment with 5 '-azacytidine restored the expression of TCF21 in 786-O (Figure4.B) and resulted in demethylation of the TCF21 (Figure4.A).

Relationship between clinicopathologic characteristics and TCF21 expression in ccRCC patients. To investigate the prognostic value of TCF21 expression for ccRCC, we assessed the association between the levels of ccRCC expression and patients' survival using Kaplan-Meier analysis with the logrank test. In $186 \mathrm{ccRCC}$ cases with prognosis information, we observed that the level of TCF21 protein expression significantly correlated with the overall survival of ccRCC patients (Figure2.D). Patients with low level of TCF21 expression had poorer survival than those with high level of TCF21 expression $(p=0.001)$. The correlation between expression level of TCF21 and patient's characteristics, such as gender (male versus female), age ( $<55$ versus $\geq 55$ years), $\mathrm{pT}$ classification (pT1 versus $\mathrm{pT} 2 \sim 4$ ), $\mathrm{pN}$ classification (pN0 versus $\mathrm{pN} 1 \sim 2$ ), pM classification (pM0 versus pM1) and Fuhrman Nuclear Grade (I/II versus III/IV) was investigated (Table3). TCF21 protein expression correlated with Fuhrman Nuclear Grade. Expression level decreased from low Fuhrman grade (I/II) to high Fuhrman grade (III/IV) tumors $(p=0.018)$. No correlation was observed between TCF21 expression and other characteristics. Cox multivariate analyse showed that lymph node metastasis (pN1 2), distant tumor metastasis (pM1),

Table3.Association of TCF21 with clinicopathologic characteristics in ccRCC

\begin{tabular}{|c|c|c|c|c|}
\hline \multirow{2}{*}{\multicolumn{2}{|c|}{$\begin{array}{l}\text { Clinicopathologic } \\
\text { characteristics }\end{array}$}} & \multicolumn{2}{|c|}{ TCF21 expression No. } & \multirow{2}{*}{$p$} \\
\hline & & Low & High & \\
\hline \multicolumn{4}{|c|}{ Age(years) } & 0.096 \\
\hline & $\geq 55$ & 57 & 34 & \\
\hline & $<55$ & 48 & 47 & \\
\hline \multicolumn{4}{|l|}{ Gender } & 0.313 \\
\hline & Male & 72 & 61 & \\
\hline & Female & 33 & 20 & \\
\hline \multicolumn{4}{|l|}{$\mathrm{pT}$} & 0.528 \\
\hline & pT1 & 60 & 50 & \\
\hline & pT2 pT4 & 45 & 31 & \\
\hline \multirow[t]{3}{*}{$\mathrm{pN}$} & & & & 0.625 \\
\hline & pNo & 71 & 52 & \\
\hline & $\mathrm{pN} 1 \sim 2$ & 34 & 29 & \\
\hline \multicolumn{5}{|l|}{$\mathrm{pM}$} \\
\hline & $\mathrm{pM} 0$ & 91 & 75 & 0.196 \\
\hline & $\mathrm{pM} 1$ & 14 & 6 & \\
\hline \multirow[t]{3}{*}{ Fuhrman } & Grade & & & \\
\hline & $\mathrm{I} / \mathrm{II}$ & 74 & 69 & $0.018^{\circ}$ \\
\hline & III/IV & 31 & 12 & \\
\hline
\end{tabular}

patients $(\mathrm{n}=186)$.
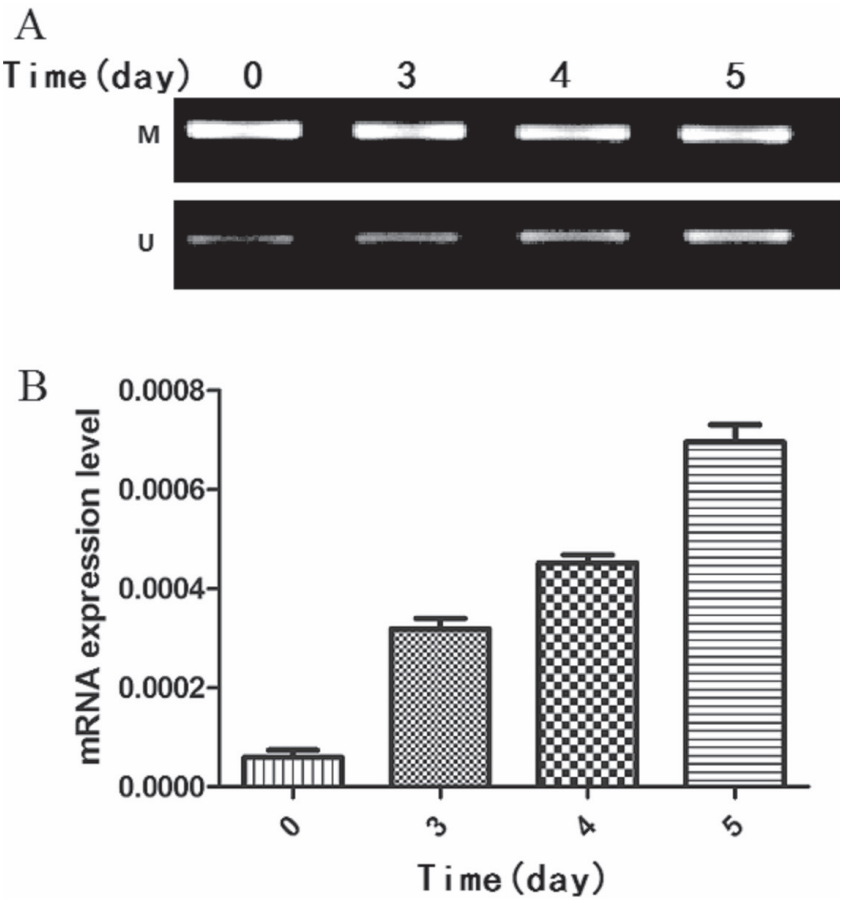

Figure 4. Methylation and expression of TCF21 in cell line 786-O. A) Methylation status after treating with 5'-azacytidine(5'-aza) 0 day, 3 days, 4 days, and 5 days in 786-O. B) Relative expression level after treat with 5 '-aza 0 day, 3 days, 4 days, and 5 days. Along the time treating with 5'-aza, methylation level of TCF21 significantly decreased and unmethylation level increased, at the same time, the expression of TCF21 significantly increased. M, methylated lane; U, unmethylated lane.

high Fuhrman grade (III and IV) and low-expression TCF21 were independent poor prognostic factors of ccRCC; However, age ( $\geq 55$ years), gender (male) and tumor size (pT2 4) were not related to the prognosis of ccRCC (Table4).

Table4. Cox multivariate Analysis of cancer specific survival (CSS) in ccRCC,

\begin{tabular}{|c|c|c|c|c|}
\hline Variable & & HR & $95 \% \mathrm{CI}$ & $p$ \\
\hline \multicolumn{5}{|l|}{ Age } \\
\hline & $\geq 55$ vs. $<55$ years & 0.823 & $0.399-1.735$ & 0.624 \\
\hline \multicolumn{5}{|l|}{ Gender } \\
\hline & Male vs. Female & 0.784 & $0.319-1.927$ & 0.596 \\
\hline \multicolumn{5}{|l|}{ pT } \\
\hline & pT1 vs.pT2 pT4 & 0.534 & $0.270-1.058$ & 0.072 \\
\hline \multicolumn{5}{|l|}{$\mathrm{pN}$} \\
\hline & pN0 vs.pN1 2 & 0.188 & $0.087-0.410$ & $<0.001^{*}$ \\
\hline \multicolumn{5}{|l|}{$\mathrm{pM}$} \\
\hline & pM0 vs.pM1 & 0.072 & $0.031-0.168$ & $<0.001^{*}$ \\
\hline \multicolumn{5}{|c|}{ Fuhrman Grade } \\
\hline & I/II vs. III/IV & 0.279 & $0.132-0.590$ & $0.001^{*}$ \\
\hline \multicolumn{5}{|c|}{ TCF21 expression } \\
\hline & High vs. Low & 4.483 & $1.842-10.912$ & $0.001^{*}$ \\
\hline
\end{tabular}


Table 5. Relationship between relative TCF21 mRNA levels and relative DNA methylation level in ccRCC samples compared to NAT samples.

\begin{tabular}{llccc}
\hline & \multicolumn{4}{c}{ Methylation } \\
& & High & Low & $p$ \\
\hline \multirow{2}{*}{ Expression } & High & 0 & 2 & 0.085 \\
& Low & 23 & 8 & \\
\hline
\end{tabular}

Relationship between TCF21 mRNA and DNA methylation in ccRCC patients. We assessed the association between the relative TCF $1 \mathrm{mRNA}$ levels and relative DNA methylation level in ccRCC samples compared to NAT samples using Fisher's exact text, and found that there was marginal significant reverse correlation $(p=0.085)$ between TCF21 mRNA levels and DNA methylation.

\section{Discussion}

Many studies demonstrate that basic-helix-loop-helix (bHLH) proteins regulate cell type-specific transcription, proliferation and transformation in a variety of tissues. The proteins have a highly conserved region therefore able to bind to DNA and to interact with each other. Members of the bHLH family can be divided into different classes. TCF 21 belongs to Class A of bHLH family. The expression of these proteins is restricted to certain tissues. TCF21 is highly expressed in the mesenchyme of developing organs that include the kidney, lung, and etc [12]. Several HLH proteins have close relationship with cancer. For example, the myc proteins are involved in oncogenesis, GCIP suppresses tumorigenesis[21, 22]. It was reported that deceased expression of TCF21 was very frequent in many cancers, our recently research found that it also happened in ccRCC [5]. In this study, we focus on the relationship between expression of TCF21 and prognosis of the patients with ccRCC, and analyze the possible reason for TCF 21 down expression. Meanwhile, we also studied the prevalence and clinical significance of TCF21 in patients with ccRCC.

Our studies demonstrate that TCF21 was frequently down expressed in ccRCC samples compared to NAT samples. We also found that TCF21 was expressed predominantly in the epithelial cells of normal kidney tissues and ccRCC tissues by immunohistochemistry assay, which was consistent with Lorraine's result, suggesting that TCF21 was involved in the pathogenesis of ccRCC [23]. According to Kaplan-Meier analyse, TCF21 protein expression in ccRCC was correlated with patient's overall survival. Patients with lower expression of TCF21 protein had shorter survival time. Additionally, we found that TCF21 protein expression correlated with Fuhrman Nuclear Grade. Expression level decreased from low Fuhrman grade (I/II) to high Fuhrman grade (III/IV) tumors ( $p=0.018$ ). Cox multivariate analyse showed that low-expression TCF21 were independent poor prognostic factors of ccRCC.

Methylation of DNA is an important reason for the down expression of genes, which is a significant epigenetic process involved in fundamental biological events such as development and cell differentiation. Aberrant DNA methylation has been reported to play a major role in carcinogenesis[6]. In the presented study, TCF21 methylation is identified as a biomarker capable of reliably differentiating between lung tumor and normal tissues. Our results demonstrated that TCF21 methylation was frequent in cell line 786-O and tissues compared to NAT samples. We also analyzed the expression of TCF21 in 786-O, and found that there was a strong inverse correlation between TCF21 mRNA levels and DNA methylation in ccRCC cell line 786-O. But TCF21 mRNA levels were not completely match with methylation levels between ccRCC and NAT in our results, so we speculated that there are some other reasons for the low expression of TCF21 in ccRCC, such as miRNA [24, $25]$ or other genes[26].

In summary, our study showed that TCF21 was expressed at lower level in ccRCC samples than in NAT samples. TCF21 may represent a predictive biomarker of poor prognosis in patients with ccRCC. Aberrant methylation was an important reason for the down-regulation of TCF21, and may be associated with tumorigenesis in ccRCC.

Acknowledgements: This study was supported in part by grants from Science and Technology Program of Shenzhen (201003099); the Promotion Program for Shenzhen Key Laboratory (CXB200903090055A, CXB201005250016A and CXB201005250017A.); and the Biobank of Complex Diseases in Shenzhen (CXC201005260001A).

\section{References}

[1] FERLAY J, SHIN HR, BRAY F, FORMAN D, MATHERS $C$ et al: Estimates of worldwide burden of cancer in 2008: GLOBOCAN 2008. Int J Cancer 2010; 127: 2893-2917. http: //dx.doi.org/10.1002/ijc.25516

[2] LOPEZ-BELTRAN A, CARRASCO JC, CHENG L, SCARPELLI M, KIRKALI Z et al: 2009 update on the classification of renal epithelial tumors in adults. Int J Urol 2009; 16: 432-443. http: //dx.doi.org/10.1111/j.1442-2042.2009.02302.x

[3] COSTA VL, HENRIQUE R, DANIELSEN SA, EKNAES M, PATRICIO P et al: TCF21 and PCDH17 methylation: An innovative panel of biomarkers for a simultaneous detection of urological cancers. Epigenetics 2011; 6: 1120-1130. http: //dx.doi.org/10.4161/epi.6.9.16376

[4.] LAM JS, PANTUCK AJ, BELLDEGRUN AS, FIGLIN RA: Protein expression profiles in renal cell carcinoma: staging, prognosis, and patient selection for clinical trials. Clin Cancer Res 2007; 13: 703-708. http: //dx.doi.org/10.1158/1078-0432. CCR-06-1864

[5] ZHOU L, CHEN J, LI Z, LI X, HU X et al: Integrated profiling of microRNAs and mRNAs: microRNAs located on Xq27.3 associate with clear cell renal cell carcinoma. PLoS One 2010; 5: e15224. http: //dx.doi.org/10.1371/journal.pone.0015224

[6] GOPALAKRISHNAN S, VAN EMBURGH BO, ROBERTSON KD: DNA methylation in development and human disease. Mutat Res 2008; 647: 30-38. http: //dx.doi.org/10.1016/ j.mrfmmm.2008.08.006 
[7] MORRIS MR, RICKETTS C, GENTLE D, ABDULRAHMAN $\mathrm{M}, \mathrm{CLARKE} \mathrm{N}$ et al: Identification of candidate tumour suppressor genes frequently methylated in renal cell carcinoma. Oncogene 2010; 29: 2104-2117. http: //dx.doi.org/10.1038/ onc. 2009.493

[8] VAN VLODROP IJ, BALDEWIJNS MM, SMITS KM, SCHOUTEN LJ, VAN NESTE L et al: Prognostic significance of Gremlin1 (GREM1) promoter CpG island hypermethylation in clear cell renal cell carcinoma. Am J Pathol 2010; 176: 575-584. http: //dx.doi.org/10.2353/ajpath.2010.090442

[9] MAJID S, DAR AA, AHMAD AE, HIRATA H, KAWAKAMI $\mathrm{K}$ et al: BTG3 tumor suppressor gene promoter demethylation, histone modification and cell cycle arrest by genistein in renal cancer. Carcinogenesis 2009; 30: 662-670. http: //dx.doi. org/10.1093/carcin/bgp042

[10] ARAI E, USHIJIMA S, TSUDA H, FUJIMOTO H, HOSODA F et al: Genetic clustering of clear cell renal cell carcinoma based on array-comparative genomic hybridization: its association with DNA methylation alteration and patient outcome. Clin Cancer Res 2008; 14: 5531-5539. http: //dx.doi.org/10.1158/ 1078-0432.CCR-08-0443

[11] MORRIS MR, GENTLE D, ABDULRAHMAN M, CLARKE $\mathrm{N}, \mathrm{BROWN} \mathrm{M}$ et al: Functional epigenomics approach to identify methylated candidate tumour suppressor genes in renal cell carcinoma. Br J Cancer 2008; 98: 496-501. http: //dx.doi.org/10.1038/sj.bjc.6604180

[12] QUAGGIN SE, VANDEN HEUVEL GB, IGARASHI P: Pod-1, a mesoderm-specific basic-helix-loop-helix protein expressed in mesenchymal and glomerular epithelial cells in the developing kidney. Mech Dev 1998; 71: 37-48. http: //dx.doi.org/10.1016/S0925-4773(97)00201-3

[13] QUAGGIN SE, SCHWARTZ L, CUI S, IGARASHI P, DEIMLING J et al: The basic-helix-loop-helix protein pod1 is critically important for kidney and lung organogenesis. Development 1999; 126(24): 5771-5783.

[14] SMITH LT, LIN M, BRENA RM, LANG JC, SCHULLER $\mathrm{DE}$ et al: Epigenetic regulation of the tumor suppressor gene TCF21 on 6q23-q24 in lung and head and neck cancer. Proc Natl Acad Sci U S A 2006; 103(4): 982-987. http: //dx.doi. org/10.1073/pnas.0510171102

[15] ANGLIM PP, GALLER JS, KOSS MN, HAGEN JA, TURLA $S$ et al: Identification of a panel of sensitive and specific DNA methylation markers for squamous cell lung cancer. Mol Cancer 2008; 7: 62. http: //dx.doi.org/10.1186/1476-4598-7-62

[16] SHIVAPURKAR N, STASTNY V, XIE Y, PRINSEN C, FRENKEL E et al: Differential methylation of a short CpG-rich sequence within exon 1 of TCF21 gene: a promising cancer biomarker assay. Cancer Epidemiol Biomarkers Prev 2008; 17: 995-1000. http: //dx.doi.org/10.1158/1055-9965.EPI-07$\underline{2808}$

[17] TESSEMA M, BELINSKY SA: Mining the epigenome for methylated genes in lung cancer. Proc Am Thorac Soc 2008; 5: 806-810. http: //dx.doi.org/10.1513/pats.200805-045TH

[18] TESSEMA M, WILLINK R, DO K, YU YY, YU W et al: Promoter methylation of genes in and around the candidate lung cancer susceptibility locus 6q23-25. Cancer Res 2008; 68(6): 1707-1714. http: //dx.doi.org/10.1158/0008-5472.CAN-07$\underline{6325}$

[19] WEISS D, BASEL T, SACHSE F, BRAEUNINGER A, RUDACK C: Promoter methylation of cyclin A1 is associated with human papillomavirus 16 induced head and neck squamous cell carcinoma independently of p53 mutation. Mol Carcinog 2011; 50: 680-688. http: //dx.doi.org/10.1002/mc.20798

[20] RICHARDS KL, ZHANG B, SUN M, DONG W, CHURCHILL J et al: Methylation of the candidate biomarker TCF21 is very frequent across a spectrum of early-stage nonsmall cell lung cancers. Cancer 2011; 117: 606-617. http: //dx.doi. org/10.1002/cncr.25472

[21] SAVINO M, ANNIBALI D, CARUCCI N, FAVUZZI E, COLE MD et al: The action mechanism of the Myc inhibitor termed Omomyc may give clues on how to target Myc for cancer therapy. PLoS One 2011; 6: e22284. http: //dx.doi. org/10.1371/journal.pone.0022284

[22] YATES DR, REHMAN I, ABBOD MF, MEUTH M, CROSS SS et al: Promoter hypermethylation identifies progression risk in bladder cancer. Clin Cancer Res 2007; 13: 2046-2053. http: //dx.doi.org/10.1158/1078-0432.CCR-06-2476

[23] ROBB L, MIFSUD L, HARTLEY L, BIBEN C, COPELAND NG et al: epicardin: A novel basic helix-loop-helix transcription factor gene expressed in epicardium, branchial arch myoblasts, and mesenchyme of developing lung, gut, kidney, and gonads. Dev Dyn 1998; 213: 105-113. http: //dx.doi. org/10.1002/(SICI)1097-0177(199809)213: 1<105: : AIDAJA10>3.0.CO;2-1

[24] SU Z, XIA J, ZHAO Z: Functional complementation between transcriptional methylation regulation and post-transcriptional microRNA regulation in the human genome. BMC Genomics 2011; 12 Suppl 5: S15. http: //dx.doi.org/10.1186/ 1471-2164-12-S5-S15

[25] BHANDARI RK, SADLER-RIGGLEMAN I, CLEMENT TM, SKINNER MK: Basic helix-loop-helix transcription factor TCF2 1 is a downstream target of the male sex determining gene SRY. PLoS One 2011; 6: e19935. http: //dx.doi. org/10.1371/journal.pone.0019935 